\title{
Effect of Demographical Characteristics on the Perception of Unorganized Retailers
}

\author{
Ganesh Das ${ }^{1}$ \\ ${ }^{I}$ (Research Scholar, Department of Commerce, Kurukshetra University, Kurukshetra, India)
}

\begin{abstract}
This article seeks to understand the impact of demographics of unorganized retailers on their perception regarding challenges of organized retailers.The study is descriptive cum analytical in nature. The research was carried on two cities (Karnal and Kurukshetra) of Haryana state. Primary data was collected from 100 small retailers through a questionnaire. The mean, standard deviation and ANNOVA is used to obtain the results.The study includes responses of only kirana stores. The size of sample taken as 100 is also small in relation to the number of shops in two cities. The study found that the unorganized retailers are facing many challenges from organized retailing. The results showed, the unorganized retailers have same type of negative perception relation to the impact organized retail format on their business.
\end{abstract}

Keywords- challenges, retailing, unorganized retailing.

\section{INTRODUCTION}

Retailing is the most dynamic sector of economy and constitute. It is one of the world's largest industry. It is in a permanent posit of change, and the pace of this change has been accelerating over last decades.India being the home of 1.25 billion people with booming economy and experiencing an attraction for the global retailers. Young population further multiplying the change by leaning towards organized retail industry such as shopping Malls and E-Retailers such as Amazon, Flipkart etc. are some of the big e-retailers which are captaining on IT comparing to previous generation of retailing. Thus in this new era of retailing, the small and unorganized retailers have to face a lot of competition and challenges from these new age retailers which are well organized. Majority of Indian retailing is still catered by the unorganized sector. In such a situation it become important to prepare the vast market of unorganized retailers to modernize and prepare them for meeting the challenges of modern organized players of retailing. To begin with it is important to understand unorganized retail sector and its problems.

\subsection{CONCEPTUAL FRAMEWORK}

Unorganized retailing refers to the traditional forms of low cost retailing that is not registered for tax purpose, for example, local kirana shops, owner operated general store, paan/beedi shops, convenience stores, hand cart and street vender's, etc. (Corporate Catalyst India, 2015) ${ }^{[1]}$ Asper the estimates, Indian retail industry is the fifth largest global destination all over the world. ${ }^{[2]}$ Total valuation of retail industry was estimated at US\$ 490 billion. The industry probably would grow at $12 \%$ p. a. (BCG analysis, 2015). ${ }^{[3]}$ It is expected to reach up to US $\$ 865$ billion by 2023. ${ }^{[4]}$ The reports showed that the share of unorganized retail in total retail business is being decreasing throughout the years. In 2011 it was approximate $92 \%$ of total retail andit will expect to come down up to $81 \%$ in 2019. (Indian retail report, 2013) ${ }^{[5]}$

\subsection{PREVIOUS WORK}

A lot of research work has been done on retail over the decade on different aspects of organized and unorganized retailing. One unorganized retailing are notable to anticipate about theoutcome of the modern retailing expect cut in their sale and profit margin. Devnathan, $(2011)^{[6]}$ of the viewthat the unorganized retailers will be badly affected by the hypermarket and mall culture in India and growth of hyper marketing and super marketing will kill them. They will not so able to compete with the modern giants. Laxman et al. $(2011)^{[7]}$ in their research find that both co-exist in India due to existence of middle class and it is not possible to tap them by global retail giants quickly. This will help the Indian retail industry to grow faster. It will beneficial to both type of retail formats.But 
the nationwide impact of organized retailing seem more critical as Guruswami et al. $(2005)^{[8]}$ explained, the long term effects of organized retail and FDI in retail will harm the Indian economy. The nation cannot be negotiated with displacements of small retailer in lakhs for some leading corporate

\subsection{NEED OF THE STUDY}

All the studies mentioned above clarified many aspect of retailing such as impact of organized retailing on unorganized retailers. But there is no such study which explains the variability in the perception of unorganized retailers on the basis of their demographics characteristics such as age, education level and profitability. The present study will explain all this.

\section{OBJECTIVES AND METHODOLOGY}

- To analyze the major challenges faced by unorganized retailers due to the entry of organized retailing.

- Toknow the difference in the perceptions of unorganized retailers due to the differences in their age, education level, profit earnings and size of the shop.

2.2 HYPOTHESIS

- $\mathrm{H}_{1}$ :There is no significant difference between the perceptions of unorganized retailers on the basis of their Age.

- $\mathrm{H}_{2}$ : There is no significant difference between the perceptions of unorganized retailers on the basis of their Education Level.

- $\mathrm{H}_{3}$ : There is no significant difference between the perceptions of unorganized retailers on the basis of their Profit Earnings.

- $\mathrm{H}_{4}$ : There is no significant difference between the perceptions of unorganized retailers on the basis of Area of the Shop.

\subsection{SCOPE OF THE STUDY}

The study is based on four main factors which the retailer feels are more challengingin current retail scenario which are stated below:-

- Market Share - is the entry of big player such as Reliance will shrinks the share of small retailers?

- Customer Loyalty-it is possible that permanent customer may shift to the organized retailer.

- Competition - organized retailing would force the small retailer to change their strategies to face the competition.

- Complementary role - Unorganized retailing may noteasily survive with the existence of organized retailing but if they can play in the areas where organized sector is unviable.

\subsection{RESEARCH DESIGN}

In order to achieve the objective of study, descriptive research design is used. The Mean, Standard Deviation and ANNOVA are used to analyze the data.

\subsection{SAMPle Design AND SAMPLE Size}

The present study is mainly concerned to the characteristics of unorganized retailing. Hence the sample contains small retailers (especially kirana store) located in two cities Karnal and Kurukshetra in the state of Haryana. In this study judgmental sampling method is used to collect information's. Personal contacts are made to each of the respondents to fill the questionnaire. The responses were collectedwith a sample of 100 unorganized retailers. 


\section{DATA ANALYSIS AND ReSUlts}

As stated earlier the data has been analyzed with the help of descriptive statistics such as mean, standard deviation. ANNOVA test is used to test the hypothesis. Thedetailed crosstab and ANNOVAis shown as under:-

Table I. Showing Descriptive statistics of variables on the basis of age of respondent

\begin{tabular}{|c|c|c|c|c|c|c|c|c|c|}
\hline \multirow[t]{3}{*}{ Group } & \multirow[t]{3}{*}{$\mathrm{N}$} & \multicolumn{8}{|c|}{ Variables } \\
\hline & & \multicolumn{2}{|c|}{ Market Share } & \multicolumn{2}{|c|}{$\begin{array}{l}\text { Customer } \\
\text { Loyalty }\end{array}$} & \multicolumn{2}{|c|}{ Competition } & \multicolumn{2}{|c|}{$\begin{array}{l}\text { Complementary } \\
\text { Role }\end{array}$} \\
\hline & & Mean & S. D. & Mean & S. D. & Mean & S. D. & Mean & S. D. \\
\hline Up to 30 & 13 & 4.00 & 0.41 & 3.54 & 0.52 & 4.08 & 0.28 & 4.24 & 0.83 \\
\hline $31-40$ & 48 & 3.88 & 0.70 & 3.71 & 0.82 & 3.83 & 0.59 & 4.04 & 0.65 \\
\hline $41-50$ & 26 & 4.12 & 0.71 & 3.65 & 0.79 & 3.92 & 0.28 & 4.08 & 0.69 \\
\hline $51-60$ & 13 & 4.23 & 0.43 & 4.00 & 0.71 & 4.08 & 0.86 & 3.92 & 0.76 \\
\hline
\end{tabular}

Table II. ANOVA and Significance Level

\begin{tabular}{|l|l|l|l|l|}
\hline Sr. No. & Variables & F-value & Sig. & Results \\
\hline 1 & Market Share & 1.42 & 0.24 & Accepted \\
\hline 2 & Customer Loyalty & 0.87 & 0.46 & Accepted \\
\hline 3 & Competition & 1.13 & 0.34 & Accepted \\
\hline 4 & $\begin{array}{l}\text { Complementary } \\
\text { Role }\end{array}$ & 0.44 & 0.73 & Accepted \\
\hline
\end{tabular}

The ANNOVA Table shows, $\mathrm{p}$-value is more than 0.05(at 5\%. significance level). So the Hypothesis $\left(\mathrm{H}_{1}\right)$ is accepted and it can be said that there is no significant difference between the perceptions of unorganized retailers on the basis of age of respondents.

Table III. Showing Descriptive statistics of variables on the basis of Education Level of respondent.

\begin{tabular}{|c|c|c|c|c|c|c|c|c|c|}
\hline \multirow[t]{3}{*}{ Group } & \multirow[t]{3}{*}{$\mathrm{N}$} & \multicolumn{8}{|c|}{ Variables } \\
\hline & & \multicolumn{2}{|c|}{ Market Share } & \multicolumn{2}{|c|}{$\begin{array}{l}\text { Customer } \\
\text { Loyalty }\end{array}$} & \multicolumn{2}{|c|}{ Competition } & \multicolumn{2}{|c|}{$\begin{array}{l}\text { Complementary } \\
\text { Role }\end{array}$} \\
\hline & & Mean & S. D. & Mean & S. D. & Mean & S. D. & Mean & S. D. \\
\hline Primary & 4 & 3.25 & 0.96 & 3.25 & 1.50 & 3.75 & 0.50 & 4.00 & 0.81 \\
\hline Secondary & 49 & 3.98 & 0.67 & 3.71 & 0.74 & 3.98 & 0.56 & 4.08 & 0.70 \\
\hline $\begin{array}{l}\text { Seiner } \\
\text { secondary }\end{array}$ & 24 & 4.88 & 0.65 & 3.75 & 0.74 & 3.88 & 0.34 & 3.96 & 0.75 \\
\hline Graduation & 23 & 4.09 & 0.54 & 3.75 & 0.75 & 3.87 & 0.69 & 4.13 & 0.63 \\
\hline
\end{tabular}


Table IV. ANOVA and Significance Level

\begin{tabular}{|l|l|l|l|l|}
\hline Sr. No. & Variables & F-value & Sig. & Results \\
\hline 1 & Market Share & 2.12 & 0.10 & Accepted \\
\hline 2 & Customer Loyalty & 0.50 & 0.68 & Accepted \\
\hline 3 & Competition & 0.44 & 0.73 & Accepted \\
\hline 4 & $\begin{array}{l}\text { Complementary } \\
\text { Role }\end{array}$ & 0.27 & 0.85 & Accepted \\
\hline
\end{tabular}

The Table 4 clearly stated that the p-value for each variable is more than 0.05 (at $5 \%$. significance level). So the null Hypothesis $\left(\mathrm{H}_{2}\right)$ is accepted that there is no significant difference between the perceptions of unorganized retailers on the basis of the education level of respondents.

Table V. Showing Descriptive statistics of variables on the basis of Profit Earning of respondent.

\begin{tabular}{|c|c|c|c|c|c|c|c|c|c|}
\hline \multirow{3}{*}{$\begin{array}{l}\text { Group } \\
\text { Profit } \\
\text { Earning } \\
\text { in } \%\end{array}$} & \multirow[t]{3}{*}{$\mathrm{N}$} & \multicolumn{8}{|c|}{ Variables } \\
\hline & & \multicolumn{2}{|c|}{ Market Share } & \multicolumn{2}{|c|}{$\begin{array}{l}\text { Customer } \\
\text { Loyalty }\end{array}$} & \multicolumn{2}{|c|}{ Competition } & \multicolumn{2}{|c|}{$\begin{array}{l}\text { Complementary } \\
\text { Role }\end{array}$} \\
\hline & & Mean & S. D. & Mean & S. D. & Mean & S. D. & Mean & S. D. \\
\hline Below 5 & 30 & 3.90 & 0.88 & 3.50 & 0.97 & 3.80 & 0.81 & 3.90 & 0.71 \\
\hline $5-10$ & 36 & 3.97 & 0.45 & 3.61 & 0.69 & 3.86 & 0.42 & 4.06 & 0.63 \\
\hline $10-15$ & 25 & 4.96 & 0.54 & 3.92 & 0.49 & 4.04 & 0.20 & 4.12 & 0.78 \\
\hline Above 15 & 9 & 4.56 & 0.53 & 4.22 & 0.76 & 4.22 & 0.44 & 4.44 & 0.53 \\
\hline
\end{tabular}

Table VI. ANOVA and Significance Level

\begin{tabular}{|l|l|l|l|l|}
\hline Sr. No. & Variables & F-value & Sig. & Results \\
\hline 1 & Market Share & 2.59 & 0.06 & Accepted \\
\hline 2 & Customer Loyalty & 3.07 & 0.31 & Accepted \\
\hline 3 & Competition & 2.12 & 0.12 & Accepted \\
\hline 4 & $\begin{array}{l}\text { Complementary } \\
\text { Role }\end{array}$ & 1.54 & 0.71 & Accepted \\
\hline
\end{tabular}

The above Table (6) described that calculated p-value is more than 0.05 (at $5 \%$. significance level). So the Null Hypothesis $\left(\mathrm{H}_{3}\right)$ is accepted and it stated that there is no significant difference between the perceptions of unorganized retailers on the basis of Profit Earning of the shopkeeper. 
Table VII. Showing Descriptive statistics of variables on the basis of Area of the Shop.

\begin{tabular}{|c|c|c|c|c|c|c|c|c|c|}
\hline \multirow{3}{*}{$\begin{array}{l}\text { Area per } \\
\text { Square } \\
\text { meter }\end{array}$} & \multirow[t]{3}{*}{$\mathrm{N}$} & \multicolumn{8}{|c|}{ Variables } \\
\hline & & \multicolumn{2}{|c|}{ Market Share } & \multicolumn{2}{|c|}{$\begin{array}{l}\text { Customer } \\
\text { Loyalty }\end{array}$} & \multicolumn{2}{|c|}{ Competition } & \multicolumn{2}{|c|}{$\begin{array}{l}\text { Complementary } \\
\text { Role }\end{array}$} \\
\hline & & Mean & S. D. & Mean & S. D. & Mean & S. D. & Mean & S. D. \\
\hline Up to 100 & 27 & 3.78 & 0.84 & 3.85 & 0.82 & 3.93 & 0.47 & 4.19 & 0.74 \\
\hline $101-200$ & 68 & 4.08 & 0.56 & 3.71 & 0.69 & 3.91 & 0.59 & 4.04 & 0.68 \\
\hline $\begin{array}{l}\text { Above } \\
200\end{array}$ & 5 & 4.00 & 0.00 & 3.00 & 1.22 & 4.00 & 0.00 & 3.60 & 0.55 \\
\hline
\end{tabular}

Table VIII. ANOVA and Significance Level

\begin{tabular}{|l|l|l|l|l|}
\hline Sr. No. & Variables & F-value & Sig. & Results \\
\hline 1 & Market Share & 2.51 & 0.11 & Accepted \\
\hline 2 & Customer Loyalty & 2.68 & 0.07 & Accepted \\
\hline 3 & Competition & 0.06 & 0.94 & Accepted \\
\hline 4 & Complementary Role & 1.58 & 0.21 & Accepted \\
\hline
\end{tabular}

In the Table 8 the p-value is more than 0.05 (at $5 \%$. significance level). So the Null Hypothesis $\left(\mathrm{H}_{4}\right)$ is accepted and it is concluded that there is no significant difference between the perceptions of unorganized retailers on the basis of age of respondents.

\section{FINDINGS AND DISCUSSION}

On the basis of above analysis and results it is clear that the unorganized retailers are facing many challenges such as:-

- $\quad$ The overall average indicates that there is negativity in the mind of unorganized retailers regarding effect on their market sharedue to the organized retailing. Most of the retailers are agreed with the statement that their permanent customers may go to the organized retailer. So there is challenge to retain that type of customer's. A large number of unorganized retailers agree with the statement that the small retailer have to change their strategies due to organized retailer. It may be any type of strategy like competitive strategies, pricing strategy and any other. With the existence of organized retailing, the survival of unorganized retailing will not easy task.

- $\quad$ For all types of challenges all the unorganized retailers have same type of perceptions. They are not differentiated on the basis of their age (as the hypothesis tested). They have same type of perceptions whether the person got education up to primary level, secondary level or even graduate. Their profit earnings and the area of shop also not make any differentiation in their perceptions regarding the impact of organized retailing.

\section{CONCLUSION AND RECOMMENDATION}

No doubt that unorganized retailer's has to face a very complex condition in relation to survive in future retailing. They have to face a very stiff competition in future from organized retailers as well as from the foreign retailers. This is the problem of all type of retailers. There is a fear of become unemployed among the retailers. They 
have not enough resources to face the competition with the giants' retailers. they have the perception that they cannot able to survive if organized retailing existing. Here some suggestion are given which will help the unorganized retailers to retain themselves in competition

- $\quad$ The small retailers have to sell the branded product at reasonable rate. Now most of the customers are brand loyal. If he gets branded products nearby the home, he will prefer to purchase the goods from the small retailer rather than the organized retailer.

- $\quad$ The organized retailers are selling just their brand name as Big Bazaar, Easyday etc. the unorganized retailers have to make also that type of own goodwill by providing good quality products and other services.

- $\quad$ Now customers feel comfortable with making payment through debit card and credit card. So the retailers have to provide this type of facility to the customers.

- In order to attract more customers, the unorganized retailers have to offer attractive promotional schemes and attractive discounts as offered by organized retailers.

[1] Corporate Catalyst India, "A Brief Report on Retail in India" (2015).

[2] S. Poornima and B. Deepha, "Impact of Global Financial Crisis on the Growth of Organized RetailDevelopment in India", International Journal of Science and Research, 3 (9), 2014, 1896-1899.

[3] BCG Analysis, (Retail Association of India, 2015).

[4] www.thehindubusinessline.com/article, 2014.

[5] Indian retail report, 2013.

[6] S. V. Devanathan, "Negative Effects of Permitting Hypermarkets and FDI in Retail Industry in India", 2012.

[7] A. Kumar, S. Hagrigi and R. Laxman, "Retailing in India: Opportunities and Challenges", International Journal of Research in Commerce and Management, 1(6), 2011.

[8] M. Guruswami, M. Sharma, J.P. Mohanty and J. T. Korah, "FDI in Retail: More Bad than Good", Economic and Political Weekly, 40(7), 2005, 619-623. 